\title{
AKUNTABILITAS PEMBANGUNAN FISIK PEMERINTAH DESA DI DESA JUNREJO KECAMATAN JUNREJO KOTA BATU
}

\author{
Nanang Bagus $\mathbf{S}^{\mathbf{1}}$;Anderias Dedo Ngara ${ }^{2}$ \\ ${ }^{1,2}$ Program StudiAdministrasiPublik, Fisip, UniversitasTribhuwanaTunggadewi \\ e-mail: nanangbagus1430@gmail.com; andrengara@gmail.com
}

\begin{abstract}
ABSTRAK
Abstrak: Akuntabilitas dalam pemerintah desa, dapat melibatkan kemampuan pemerintah desa untuk mempertanggungjawabkan berbagai kegiatan yang dilaksanakan yang masih ada kaitannya dengan masalah pembangunan pemerintahan desa. Jenis penelitian yang digunakan, jenis penelitian kualitatif menggunakan teknik pengumpulan data melalui wawancara, observasi, dokumentasi, pengambilan sampel secara purposive sampling. Untuk menguji keabsahan data, peneliti menggunakan teknik triangulasi. Analisis data dilakukan dengan cara reduksi data, penyajian data, dan penarikan kesimpulan.Hasil penelitian menunjukan bahwa tahapan perencanaan dalam pembangunan desa di Desa Junrejo kurang efektif dimana dilakukan dengan melihat proses musrembang desa untuk membahas rencana kegiatan pembangunan desa serta bagaimana proses pengelolaan pembangunan desa, dimana dalam tahapan perencanaan ini di ukur dengan jumlah pihak yang berpartisipasi dalam proses musrembang desa. Faktor penghambat akuntabilitas pembangunan fisik desa di desa Junrejo adalah masalah kemampuan sumber daya manusia, yang mana sebagian besar aparatur desa masih berpendidikan SMA/sederajat sehingga akan mengalami kesulitan jika terjadi perubahan kebijakan, masalah berikutnya adalah keterbukaan informasi yang dirasakan masih cukup lambat serta kelembagaan dan partisipasi masyarakat yang belum dimaanfaatkan secara maksimal.
\end{abstract}

Kata Kunci: Akuntabilitas, pembangunan, dana desa

Abstract: The accountability in the village government can be involved the capability of the village government to take a part about some activities that still organize which have some relationship with the problem in village government. This research used qualitative design and the technique to collecting the data was using interview, observation, and documentation. The sampling technique was purposive sampling technique. To know the reliability, the researcher used triangulation technique. The data analysis did by data reduction, data display and takes the conclusion. The result of this research explains that the planning stages in village development at Junjero village was not effective, it was still fair. It could be seen that the government and the society was doing a discussion to discuss about the planning in development and the way how to manage the development, the participants were a little that have the awareness to make a change. The accountability factors that inhibit the village development is the human resource, that some of them have limited education, some of them just graduate in senior high school, it affects that if a positive change applying, some of them will refuse the change. The other problem is the society still not open minded, they still inflexible with the information and they was not take the advantage of the village property well.

Key words: accountability, development, village fund 


\section{PENDAHULUAN}

Akuntabilitas ialah suatu kewajiban untuk memberikan pertanggung-jawaban atau menjawab dan menerangkan kinerja serta tindakan seseorang/pimpinan suatu unit organisasi kepada suatu pihak yang memiliki hak atau yang berwenang meminta pertanggungjawaban. Akuntabilitas akan semakin baik apa bila didukung oleh suatu sistem akuntansi yang menghasilkan informasi yang akurat, handal, tepat, waktu, serta dapat dipertanggungjawabkan (Komang, 2014:11).

Akuntabilitas dalam pemerintah desa, dapat melibatkan kemampuan pemerintah desa untuk mempertanggungjawabkan berbagai kegiatan yang dilaksanakan yang masih ada kaitannya dengan masalah pembangunan dan pemerintahan desa. Pertanggungjawaban yang dimaksud adalah masalah finansial yang terdapat dalam Anggaran Pendapatan Belanja Desa (APBDes) dengan Pendapatan Asli Desa (PADes), Alokasi Dana Desa (ADD), dan Dana Desa (DD) termasuk berbagai komponen di dalamnya, (Suherman, 2016: 29).

Dalam ketentuan Permendagri nomor 20 Tahun 2018 disampaikan bahwa pengelolaan keuangan desa merupakan keseluruhan kegiatan yang meliputi: perencanaan, penganggaran, penatausahaan, pelaporan, pertanggungjawaban dan atau suatu pengawasan keuangan desa, sehingga dengan hak otonom tersebut diharapkan desa dapat mengelola keuangannya tersebut secara mandiri, baik dalam mengelola pendapatan maupun dalam mengelola pembelanjaan anggaran, (Seraya, 2017: 5).

Desa dikenal sebagai salah satu ujung tombak dari organisasi pemerintah dalam mencapai keberhasilan dari urusan pemerintahan yang asalnya dari pemerintah pusat. Perihal ini disebabkan karena desa lebih dekat dengan masyarakat sehingga program yang disampaikan dari pemerintah lebih cepat tersampaikan (Fajri et al., 2016: 18). Pembangunan Nasional dapat terwujud apabila didukung oleh penyelenggaran pemerintahan yang baik dipusat maupun didaerah termasuk di tingkat desa dan kelurahan. Pembangunan dapat diartikan sebagai suatu proses perubahan yang terus menerus untuk keadaan yang lebih baik berdasarkan norma-norma tertentu serta suatu usaha atau rangkaian usaha pertumbuhan dan perubahan yang dibuat secara terencana yang dilakukan secara sadar, oleh suatu bangsa, negara dan pemerintah, menuju modernitas dalam rangka pembinaan dan pengembangan bangsa (Seraya, 2017: 6).

Salah satu wujud dari pelaksanaan desentralisasi fiskal melalui pemberian/ penyaluran dana, perimbangan dari pemerintah kabupaten untuk desa biasa dikenal dengan nama Alokasi Dana Desa (ADD). Dimana pelaksanaan ADD seringkali dijadikan sebagailahan bagi kepala desa, untuk melakukan kecurangan dengan menggunakannya untuk mencapai kepentingan pribadi, bukan untuk meningkatkan pemberdayaan masyarakat desa. Kepala desa sebagai pemimpin kegiatan pemerintahan yang ada di desa merupakan suatu pihak yang dikenal sebagai seorang yang paling bertanggung jawab dalam pengelolaan ADD dimana kedudukan kepala desa sebagai ketua Tim Pelaksana Desa (TPD) dalam mengelola ADD. Realisasinya justru terdapat lebih banyak kepala desa yang tersandung dalam masalah penyalahgunaan ADD.Selainitu, dalam penyampaian laporan realisasi pelaksanaan APBDes semester pertama dimana laporan laporan realisasi atau penggunaan dana desa yang merupakan bagian yang tak terpisahkan dari laporan realisasi APBDes semester pertama menunjukkan pemerintah desa Junrejo terlambat dalam melaksanakan penyampaian kepada Walikota Batu.

Pembangunan desa dapat terlaksana dengan baik apa bila didukung dengan bantuan dari aparat desa khususnya kapala desa. Kepala desa memiliki tanggung jawab dalammelaksanakan pembangunan desa sehingga pembangunan terlihat merata dan semua rancangan pembangunan dapat terealisasi secara maksimal. Untuk mengelola dana desa agar pembangunan fisik 
terealisasi sesuai rencana. Dimana aspirasi masyarakat sangat penting untuk mengetahui apaapa saja yang dibutuhkan dan yang tidak dibutuhkan sehingga pembangunan akan terwujud dengan tepat.

Akuntabilitas menurut Andrianto (2014: 23) merupakan setiap kegiatan dan hasil akhir kegiatan yang harus dapat dipertanggungjawabkan kepada rakyat. Sehinga menjadi sangat penting bagi pemerintah desa untuk mengimplementasikan akuntabilitas ini, pada pembangunan fisik yang di laksanakan di desa. sesuai dari latar belakang maslah diatas. Maka penulis dapat merumuskan mengenai bagaimana akuntabilitas Pemerintah Desa Junrejo dalam pengelolaan pembangunan fisik didesa serta faktor apa sajakah yang mempengaruhi akuntabilitas tersebut.

\section{METODE PENELITIAN}

Jenis penelitian ini menggunakan kualitatif, dengan mengambil lokasi penelitian di Desa Junrejo. Pada penelitian ini peneliti memperoleh data dari data primer dan data sekunder dengan teknik pengumpulan data melalui observasi, wawancara dan dokumentasi. Pengambilan sampel pada penelitian ini dilakukan dengan penarikan sampel secara purposive sampling, dan yang menjadi instrumen pada penelitian ini yaitu peneliti sendiri, daftar pertanyaan, camera hand phone, dan alat tulis. Pemeriksaan keabsahan data menggunakan triangulasi teknik, yaitu melalui observasi, wawancara dan dokumentasi, kemudian data yang terkumpul dianalisis secara kualitatif dengan cara reduksi data, penyajian data dan penarikan kesimpulan.

\section{HASIL DAN PEMBAHASAN}

\section{Akuntabilitas Pembangunan Fisik Pemerintah Desa Junrejo}

Pembangunan di desa Junrejo yang telah memberikan hasil yang cukup memuaskan, namun demikian untuk memberikan hasil yang lebih baik dalam upaya meningkatkan kesejahteraan sosial ekonomi masyarakat, maka pelaksanaan pembangunan di desa tersebut harus dapat memberikan hasil yang lebih besar lagi terhadap perubahan sosial ekonomi masyarat dengan meningkatkan partisipasi masyarakat. Pembangunan desatidak dapat dilepaskan dengan keuangan desa dikelola berdasarkan praktik-praktik pemerintahan yang baik. Asas-asas Pengelolaan Keuangan Desa sebagaimana tertuang dalam Permendagri Nomor 113 Tahun 2014 yaitu transparan, akuntabel, partisipatif serta dilakukan dengan tertib dan disiplin anggaran.

Sesuai dengan Undang-Undang Nomor 6 tahun 2014 tentang Desa, bahwa pengelolaan kekayaan milik desa harus memenuhi asas akuntabel. Keuangan desa merupakan salah satu kewajiban pemerintah pusat dalam penyelenggaraan pemerintahan yang bertujuan untuk memberikan wewenang kepada pemerintah desa agar bisa mengelola, memberikan kebijakan, dan mengatur keuangan untuk kepentingan masyarakat pedesaan. Tujuan berikutnya agar dapat memfokuskan pelaksanaan pemerintahan desa oleh pemerintah desa langsung tanpa ada campur tangan dari pemerintah pusat, pemerintah pusat hanya sebagai pengawas dan mengevaluasi serta memberikan masukan untuk pemerintahan desa.

Salah satu penggunaan Dana Desa digunakan untuk pembangunan infrastruktur. Sebelum melaksanakan pembangunan infrastruktur, harus dilaksanakan perencanaan. Seperti yang dilaksanakan oleh Pemerintah Desa Junrejo, rencana pembangunan infrastruktur dirumuskan bersama masyarakat dan pelaksanaan serta pengawasannya harus melibatkan masyarakat Desa

Junrejo. Kemudian Pemerintah Desa Junrejo memiliki kewajiban memberikan laporan pertanggungjawaban setelah pelaksanaan kegiatan pembangunan infrastruktur kepada 
pemerintahan di atasnya dan masyarakat, baik masyarakat yang tinggal di lingkungan desa maupun yang tinggal di luarDesa.

Terkait proses dalam pembangunan desa, Pemerintah Desa Junrejo terlebih dahulu menyusun tim pelakasana yang terdiri dari Kepala Desa selaku Penanggung Jawab Operasional Kegiatan (PJOK), Sekretaris Desa Selaku Penanggung Jawab AdministrasiKegiatan (PJAK), KepalaUrusan Keuangan Selaku Bendahara Desa dan di bantu oleh Lembaga Kemasyarakatan di Desa. Selanjutnya, proses dalam pembangunan desa terdiri dari tahapan perencanaan, pelaksanaan dan pertanggungjawaban.

Hasil penelitian menunjukan bahwa tahapan perencanaan dalam pembangunan desa di Desa Junrejo kurang efektif dimana dilakukan dengan melihat proses musrembang desa untuk membahas rencana kegiatan pembangunan desa serta bagaimana proses pengelolaan pembangunan desa, dimana dalam tahapan perencanaan ini di ukur dengan jumlah pihak yang berpartisipasi dalam proses musrembang desa.

Perencanaan dalam pembangunan desa adalah tahapan awal bertujuan untuk menyusun kegiatan pelaksanaan pembangunan desa yang dimulai dari forum Musyawarah Perencanaan Pembangunan Desa (Musrenbangdes). Musrenbangdes tersebut merupakan forum pembahasan usulan rencana kegiatan pembangunan di tingkat desa yang berpedoman pada prinsip-prinsip Perencanaan Pembangunan Partisipasi Masyarakat Desa (P3MD). Prinsip tersebut mengharuskan keterlibatan masyarakat dalam pengambilan keputusan dan menentukan pembangunan yang akan dilaksanakan khususnya yang berlokasi di desa yang bersangkutan, sehingga benar-benar dapat merespon kebutuhan/aspirasi yang berkembang. Implementasi program pembangunan desa juga dilaksanakan dalam rangka pemberdayaan masyarakat dan menekankan proses motivasi berpartisipasi dalam pembangunan desa.

Pemerintah Desa menyusun perencanaan pembangunan desa sesuai dengan kewenangannya dengan mengacu pada perencanaan pembangunan kabupaten/kota. Perencanaan Pembangunan Desa meliputi RPJM Desa dan RKP Desa yang disusun secara berjangka dan ditetapkan dengan Peraturan Desa. Rencana Pembangunan Jangka Menengah Desa (RPJM Desa) untuk jangka waktu 6 (enam) tahun sedangkan Rencana Pembangunan Tahunan Desa atau yang disebut Rencana Kerja Pemerintah Desa (RKP Desa) untuk jangka waktu 1 (satu) tahun. RKP Desa merupakan penjabaran dari Rencana Pembangunan Jangka Menengah Desa.

Rancangan RKP Desa dilampiri Rencana Kegiatan dan Rencana Anggaran Biaya (RAB), yang telah diverifikasi oleh tim verifikasi. Selanjutnya, Kepala Desa menyelenggarakan Musrenbangdes yang diadakan untuk membahas dan menyepakati rancangan RKP Desa. Rancangan RKP Desa memuat rencana penyelenggaraan pemerintahan desa, pelaksanaan pembangunan, pembinaan kemasyarakatan, dan pemberdayaan masyarakat desa.

Kesimpulan peneliti dalam mengukur akuntabilitas dalam perencanaan yang sudah melibatkan elite desa berdasar pada hasil wawancara yang dihimpun peneliti yang berkaitan dengan pelibatan masyarakat, dari ketiga informan menyampaikan bahwa aktor yang dilibatkan dalam perencanaan adalah pengurus desa, tokoh masyarakat, dan tokoh agama. Artinya, partisipasi tetap berjalan walaupun belum maksimal, serta dalam proses musrembang pada tahapan perencanaan, masalahnya adalah kurangnya transparansi informasi dari pemerintah desa yang berdampak pada rendahnya tingkat partisipasi masyarakat luas dan pengawasan dari masyarakat desa baik secara lembaga maupun individu dalam setiap proses. Pendapat diatas senada dengan hasil penelitian Sumiati (2014), yang menyimpulkan skala prioritas dalam pelaksanaan program lebih diutamakan. Hal tersebut dikarenakan begitu banyaknya aspirasi yang dikemukakan oleh masyarakat yang berdampak terhadap tidak terlaksananya program 
lainnya. Selain begitu banyaknya aspirasi, kegagalan dalam tahapan perencanaan terlihat dari menggelembungnya dana pelaksanaan program desa lainnya yang kemudian menghapus program kerja lainnya yang telah direncanakan seperti yang terjadi pada program kerja pemilihan kepala desa dengan program kerja perjalanan dinas luar daerah sekretaris desa.

Dalam pelaksanaan pembangunan desa keuangan desa, terdapat beberapa prinsip umum yang harus ditaati yang mencakup penerimaan dan pengeluaran dana pembangunan. Prinsip itu diantaranya bahwa seluruh penerimaan dan pengeluaran desa dilaksanakan melalui Rekening Kas Desa. Pencairan dana dalam Rekening Kas Desa ditandatangani oleh Kepala Desa dan Bendahara Desa. Namun khusus bagi desa yang belum memiliki pelayanan perbankan di wilayahnya maka pengaturannya lebih lanjut akan ditetapkan oleh pemerintah daerah kabupaten/kota. Dengan pengaturan tersebut, maka pembayaran kepada pihak ketiga secara normatif dilakukan melalui transfer ke rekening bank pihak ketiga. Dalam pelaksanaannya, Bendahara Desa dapat menyimpan uang dalam kas desa pada jumlah tertentu untuk memenuhi kebutuhan operasional pemerintah desa. Batasan jumlah uang tunai yang disimpan dalam kas desa ditetapkan dengan peraturan bupati/walikota. Selain itu, agar operasional kegiatan berjalan lancar, dimungkinkan juga pembayaran kepada pihak ketiga dilakukan dengan menggunakan kas tunai melalui pelaksana kegiatan (panjar kegiatan). Pemberian panjar kepada pelaksana kegiatan dilakukan dengan persetujuan terlebih dahulu dari kepala desa setelah melalui verifikasi Sekretaris Desa.

Menurut Sukesi (2007) sebagai satu kesatuan masyarakat hukum yang memiliki batas wiayah yurisdiksi dan berwenang untuk mengatur dan mengurus kepentingan masyarakat setempat berdasarkan asal-usul dan adat istiadat setempat, maka desa memerlukan perhatian secara proporsional dengan memposisikan lembaga desa dalam satu koridor hukum yang dapat menjamin eksistensi desa dengan mempertimbangkan asas keaneka ragaman, partisipasi, otonomi asli, demokratisasi serta pemberdayaan masyarakat. Dana desa dalam pembangunan desa adalah merupakan dana perimbangan pemerintah pusat dan daerah yang dimaksudkan untuk membiayai program pemerintahan desa dalam melaksanakan kegiatan pemerintahan dan pemberdayaan masyarakat.

Pelaksaan pembangunan desa bersumber dari anggaran pendapatan dan belanja daerah tahun berjalan. Dalam pelaksanaan pembangunan desa juga masih dapat melihat partisipasi aktif dari lapisan masyarakat dengan adanya swadaya dari masyarakat yang tercermin dari data paparan pembangunan desa. Pelaksanaan kegiatan-kegiatan yang pembiayaaannya bersumber dari dana desa sepenuhnya dilaksanakan oleh Tim Pelaksana Desa. Untuk mendukung keterbukaan dan penyampaian informasi secara jelas kepada masyarakat, maka di setiap kegiatan fisik wajib dilengkapi dengan papan informasi kegiatan yang dipasang di lokasi kegiatan. Papan informasi tersebut sekurang-kurangnya memuat nama kegiatan, volume kegiatan, besaran anggaran dari dana desa maupun swadaya masyarakat, dan waktu pelaksanaan kegiatan seperti yang telah disepati dari Musrenbangdes.

Semua penerimaan dan pengeluaran desa didukung oleh bukti yang lengkap dan sah serta ditandatangani oleh Kepala Desa dan Bendahara Desa. Pada tahapan pelaksanaan pembangunan desa di Desa Junrejo, hasil penelitian menunjukan bahwa dalam tahapan pelaksanaan dalam pembangunan desa di Desa Junrejo ini, dari setiap pembangunan desa yang dilakukan. Namun dikarenakan kurangnya transparansi informasi terkait pelaksanaan perencanaan kegiatan oleh pemerintah desa kepada masyarakat, sehingga pencapaian tujuan pengelolaan dana desa dalam pembangunan desa yang dilakukan di Desa Junrejo belum efektif. 
Pelaksanaan kegiatan pembangunan desa sebagaimana ditetapkan dalam APBDes yang pembiayaannya bersumber dari dana desa sepenuhnya dilaksanakan oleh Tim PelaksanaDesa, selanjutnya guna mendukung keterbukaan dan penyampaian informasi secara jelas kepada masyarakat, maka pada setiap pelaksanaan kegiatan pembangunan desa wajib dilengkapi dengan Papan Informasi Kegiatan yang dipasang di lokasi kegiatan. Dengan demikian tahapan pelaksanaan pembangunan fisik di Desa Junrejo berjalan dengan baik, akan tetapi walaupun proses pembagunan berjalan dengan baik namun tahapan pelaksaan ini harus melibatkan masyarakat sebagai tim evaluasi atau tim pengawas dari setiap egiatan yang di adakan oleh pemerintah desa.

Selanjutnya, tahapan pertanggungjawaban pembangunan desa, hasil penelitian menunjukan bahwa tahapan pertanggung-jawaban kurang efektif, dimana penyusunan Laporan Pertanggungjawaban (LPJ) tidak disusun oleh Pemeintah Desa Junrejo dan tidak adanya evaluasi kegiatan yang seharusnya dilakukan bersama masyarakat Desa Junrejo. Maka tahapan petanggungjawaban yang dilakukan oleh pemerintah Desa Junrejo dapat dikatakan kurang efektif.

Hasil penelitian di atas senada dengan penelitian Rahum (2014), bahwa belum terjadi pertanggungjawaban secara langsung kepada masyarakat, hal tersebut terjadi karena belum ada transparansi atau keterbukaan oleh Pemerintah Desa sebagai pelaksana kepada masyarakat dalam bentuk informasi pembangunan desa. Analisis tersebut didukung oleh kenyataan bahwa elaksanaan kegiatan pembangunan desa yang didanai dana desa diserahkan kepada Kepala Dusun atau Perangkat Desa, sedangkan sebagian besar tidak menginformasikan kepada masyarakat tentang dana yang diterima dari pemeintah Kabupaten/Kota.

Dalam melaksanakan tugas, kewenangan, hak, dan kewajibannya dalam pengelolaan keuangan desa, kepala desa memiliki kewajiban untuk menyampaikan aporan. Laporan tersebut bersifat periodik semesteran dan tahunan, yang disampaikan ke Bupati/Walikota dan ada juga yang disampaikan ke BPD. Rincian laporan sebagai berikut:

1. Laporan kepada Bupati/Walikota (melalui camat):

2. Laporan Semesteran Realiasasi Pelaksanaan APB Desa;

3. Laporan Pertanggungjawaban Realisasi Pelaksanaan APB Desa kepada Bupati/Walikota setiap akhir tahun anggaran.

4. Laporan Realisasi Penggunaan Dana Desa

5. Laporan kepada Badan Permusyawaratan Desa (BPD)

6. Laporan Keterangan Pertanggungjawaban Realisasi Pelaksanaan APB Desa terdiri dari Pendapatan, Belanja, dan Pembiayaan.

Laporan Realiasasi Pelaksanaan APB Desa disampaikan kepada Bupati/Walikota melalui camat, terdiri dari:

1. Laporan Semester Pertama, disampaikan paling lambat pada akhir bulan Juli tahun berjalan;

2. Laporan Semester AkhirTahun, disampaikan paling lambat pada akhir bulan Januari tahun berikutnya.

Dari berbagai sumber data/informan yang dikumpulkan, peneliti dapat menganalisis bahwa akuntabilitas pembangunan fisik di Desa junrejo berjalan dengan baik walaupun belum maksimal. Keberhasilan penerapan akuntabilitas tidak terlepas dari keterlibatan berbagai pihak dalam hal ini: BPD, LSM, tokoh masyarakat, tokoh agama dan tokoh adat dalam menyukseskan program pembangunan desa. inilah yang membedakan penerapan akuntabilitas dengan 
penelitian sebelumnya yang tidak melibatkan berbagai elemen dalam proses pembangunan. Suksesnya penerapan akuntabilitas di Desa Junrejo sejalan dengan teori yang di gagas oleh Ellwood (2015), bahwa akuntabilitas program berkaitan dengan masalah pencapaian tujuan (efektifitas) dan mempertimbangkan alternatif program yang memberikan hasil optimal dengan biaya minimal. Akuntabilitas program berkaitan dengan unit-unit dan birokrat secara individual yang melakukan aktivitas bersama untuk mencapai efektivitas program, sehingga dengan penerapan akuntabilitas ini program yang disusun dan direncanakan dapat dipertanggungjawabkan.

Sebagai masukan peneliti untuk mendorong terwujudnya efektivitas pembangunan desa dengan mengutip pendapat Arianto \& Rohman (2019) bahwa harus ada strategi pemerintah desa dalam pembangunan berkenaan dengan pelibatan masyarakat. Salah satu strategi pembangunan melibatkan masyarakat adalah dengan membentuk tim pelaksana kegiatan (TPK) yang bertugas sebagai pelaksana kegiatan di lapangan, yang dipilih langsung dari masyarakat. Pelaksana tugas tersebut meliputi juga pengawasan langsung tehadap jalannya pembangunan yang sedang terjadi. Tujuanya lain dari TPK ini dalah meningkatkan pasrtisipasi masyarakat serta meningkatkan pemberdayaan masyarakat desa setempat.

\section{Faktor Penghambat Akuntabilitas Pembangunan Fisik}

\section{Sumber Daya Manusia}

Sumber daya manusia yang masih sangat terbatas, dimana kondisi Sumber Daya Manusia masih sangat terbatas dan belum sesuai dengan standar kompetensi, baik dari kualitas pendidikan ataupun pengalaman kerja yang dimiliki perangkat Desa Junrejo yang masih berpendidikan tamatan SMA

Hal ini terbukti dengan ketidak mampuan pelaksana kegiatan pembangunan desa dalam membuat Laporan Pertanggungjawaban (LPJ) sehingga harus menggunakan bantuan pihak ketiga yang bukan dari Tim pelakasana pembangunan desa juga bukan merupakan bagian dari Perangkat Desa Junrejo. Permasalahan sumber daya manusia masih menjadi momok yang selalu menghantui jalannya program pembangunan desa, penelitian sebelumnya juga menemukan hal yang sama terkait minimnya sumber daya manusia, sehingga penting untuk meningkatkan pengetahuan sumber daya aparatur desa melalui bentuk pelatihan.

\section{Informasi}

Dari hasil penelitian salah satu faktor penghambat adalah kurangnya informasi yang diperoleh masyarakat dari Pemerintah Kabupaten/Kota sehingga masyarakat tidak mengetaui sama sekali fungsi mereka sebagai tim pengawas langsung dalam pembangunan desa, melainkan masyarakat hanya mengetahui bahwa ada dan sudah terlaksananya pembangunan yang ada di Desa. Sebagaimana yang dikatakan Arief (2014) dalam implementasi kebijakan sumber informasi yang berbeda juga akan melahirkan interpretasi yang berbeda pula. Agar implementasi berjalan efektif, siapa yang bertanggungjawab melaksanakan sebuah keputusan harus mengetahui apakah mereka dapat melakukannya. Sesungguhnya implementasi kebijakan harus diterima oleh semua personel dan harus mengerti secara jelas dan akurat mengenai maksud dan tujuan kebijakan. Jika para aktor pembuat kebijakan telah melihat ketidak jelasan spesifikasi kebijakan sebenarnya mereka tidak mengerti apa sesunguhnya yang akan diarahkan. Para implemetor kebijakan bingung dengan apa yang akan mereka lakukan sehingga jika dipaksakan tidak akan mendapatkan hasil yang optimal. Tidak cukupnya komunikasi kepada para implementor secara serius mempengaruhi implementasi kebijakan. 
Informasi yang disampaikan oleh pemerintah desa tarkait pembangunan desa masih kurang jelas. Selain tidak pernah melakukan sosialisasi sebelumnya, dalam tahapan musrembang desa pemerintah desa juga hanya sekedar menyebutkan nominal dana Desa yang diperoleh dan digunakan dalam pembangunan desa. Namun tidak ada penjelasan lebih lanjut terkait dengan tujuan pembangunan desa, bagaimana penggunaan anggaran tersebut, atau bagaimana peran masyarakat dalam setiap tahapan pembangunan desa tersebut. Masalah keterbatasan informasi di Desa Junrejo dapat dianalisis dengan menggunakan dimensi akuntabilitas yang digagas oleh coghill (2014) bahwa masyarakat seharusnya dapat mengetahui seberapa jauh keadilan, kejujuran dan kebenaran (efesiensi dan efektifitas) telah dilaksanakan oleh penyelanggara pemerintahan dalam setiap hubungannya (dealing) degan masyarakat.

\section{Partisipasi Masyarakat}

Berdasarkan hasil penelitian setiap tahapan perencanaan, pelaksanaan dan pertanggungjawaban dalam pembangunan desa dalam upaya meningkatkan pembangunan fisik Di Desa Junrejo masih kurang baik. Hal ini daris etiap proses tahapan pembangunan desa terkadang belum sesuai dengan prinsip pembangunan desa yang ditetapkan. Pengelolaan dana desa dalam meningkatkan pembangunan fisik Di Desa Junrejo, dilakukan dengan tiga proses tahapan yaitu perencanaan, pelaksanaan dan pertanggungjawaban masih kurang baik, dimana terkait dengan masih kurangnya sosialisasi dalam setiap musrembang desa sehingga mengakibatkan kurangnya partisipasi masyarakat dikarenakan kurangnya informasi yang diperoleh masyarakat desa, sehingga berdampak pada rendahnya partisipasi dan pengawasan dari masyarakat desa baik secara lembaga ataupun individudalam setiap tahapan pembangunan desa. Kondisi tersebut berdampak pula belum efektifnya pencapaian tujuan pembangunan desa dalam meningkatkan pembangunan.

Masalah partisipasi yang terjadi di Desa Junrejo dapat digolongkan sebagai pembangunan non partisipatif jika merujuk pada teori yang digagas kartasasmita (2015), pembangunan non partisipatif yang dimaksudkan adalah pembangunan yang hanya menguntungkan segolongan kecil masyarakat tapi tidak melibatkan rakyat secara keseluruhan. Padahal yang di utamakan dalam proses pembangunan adalah partisipasi masyarakat atau jika digolongkan menurut Oakley (2015) adalah pembangunan partisipatif. Pembangunan partisipatif yang dimaksudkan Oaklay adalah terlibat dan ikutsertanya masyarakat sesuai dengan mekanisme proses politik dalam suatu negara, turut menentukan arah, strategi, dan kebijaksanaan pembangunan yang dialakukan pemerintah.

\section{KESIMPULAN}

1. Akuntabilitas pembangunan fisik yang diupayakan oleh pemerintah desa Junrejo adalah dengan jalan melibatkan berbagai pihak dalam perencanaan pembangunan fisik desa, pihak tersebut antara lain; Badan Permusyawaratan Desa, Lembaga Pemberdayaan Masyarakat Desa, Kepala Dusun, Ketua/pengurus RW, Ketua/pengurus RT dan tokoh-tokoh di desa Junrejo.

2. Apabila dilihat dari aspek pelaksanaan pembangunan fisik yang diupayakan oleh pemerintah desa Junrejo mewujudkan akuntabilitas sudah bagus dapat dilihat dari alur pertanggungjawaban transparansi pengelolaan Dana di Desa Junrejo untuk pembangunan infrastruktur tahun 2017 yang terdiri dari enam tahapan yang mana hal sesuai dengan Undang-Undang Nomor 6 Tahun 2014 Tentang Desa dan sesuai Perda Kota Batu Nomor 49 Tahun 2015 Tentang Pertangungjawaban Pembangunan Desa. 
3. Faktor penghambat akuntabilitas pembangunan fisik desa di desa Junrejo adalah masalah kemampuan sumber daya manusia, yang mana sebagian besar aparatur desa masih berpendidikan SMA/sederajat sehingga akan mengalami kesulitan jika terjadi perubahan kebijakan, masalah berikutnya adalah keterbukaan informasi yang dirasakan masih cukup lambat serta kelembagaan dan partisipasi masyarakat yang belum dimaanfaatkan secara maksimal.

\section{DAFTAR PUSTAKA}

Andrianto, Nico. 2014. Good Goverment. Transparansi dan Akuntabilitas PublikMelalui eGoverment. Bayu Media. Palangkaraya.

Arianto, Y. V., \& Rohman, A. (2019). Efektivitas Penggunaan Alokasi Dana Desa (ADD) Dalam Pelaksanaan Pembangunan Desa. JISIP: Jurnal Ilmu Sosial dan Ilmu Politik, 7(2).

Fajri, R., E. Setyowati, Siswiyanto. 2016. Akuntabilitas Pemerintah Desa Pada Pengelolaa Alokasi Dana Desa. Jurnal. Administrasi Publik (JAP) Vol. 3, No. 7: 1099-1104.

Istoqomah, Siti. 2015. Evektivitas Kinerja Badan Permusyawaratan Desa DalamMeningkatkan Akuntabilitas Pengelolaan Keuangan Desa. Jurnal. Kebijakan dan Manajemen Publik. Vol. 3, No, 1: 1-18.

Komang, Arianti, P. 2014. Akuntabilitas Kualitas Audit Pemerintah Daerah. e-Journal Akuntansi Univeristas Pendidikan Ganesha. Vol 2, No 1 Tahun 2014.

Rahum, Abu. 2015. Pengelolaan Alokasi Dana Desa (ADD) Dalam Pembangunan Fisik Desa Krayan Makmur Kecamatan Long Ikis Kabupaten Paser. eJournal Ilmu Pemerintahan, 2015: 3 (4) 1623-1636 ISSN 00000000 ejournal.ip.fisip.unmul.ac.

Seraya, Yuddy. 2017. Akuntabilitas Pengawasa Keuangan Pemerintah Desa. e-Journal Pascasarjana Universitas Diponogoro Semarang. Vol 4 No 6 Tahun 2017.

Suherman, Toha. 2016. Pertanggung Jawaban Penyelenggaraan Pemerintahan. Penelitian Masalah Hukum. BP-HN. Jakarta.

Undang-undang Republik Indonesia Nomor 6 Tahun 2014 Tentang Desa. 